garth, 1991

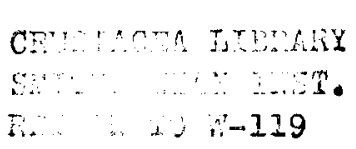

In: Galapagos Marine Invertebrates, 1. J. James, ed., Plenum Publishing Corporation, New York, 1991, 474 pp.

Chapter 5

\title{
Taxonomy, Distribution, and Ecology of Galápagos Brachyura
}

\section{JOHN S. GARTH}

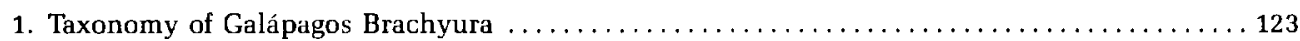

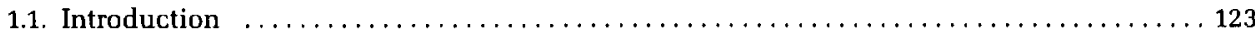

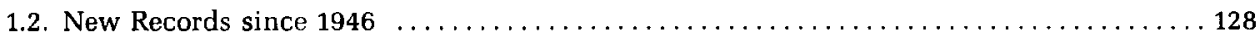

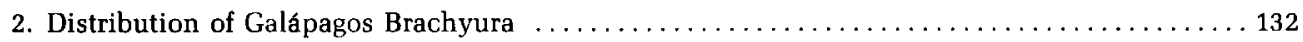

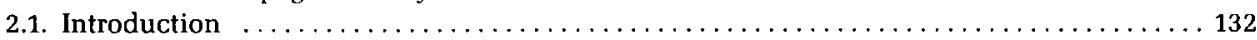

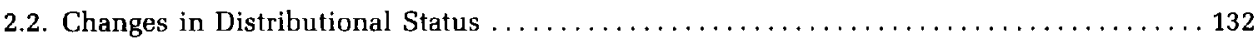

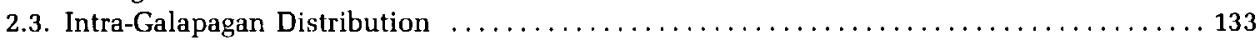

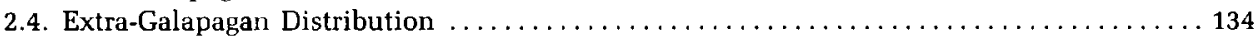

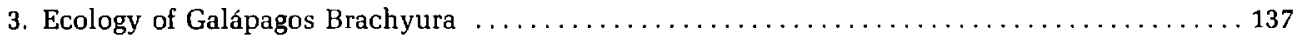

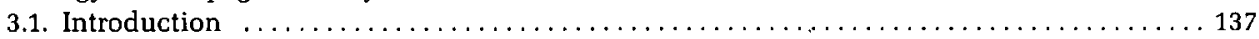

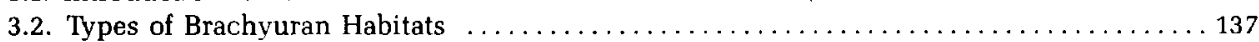

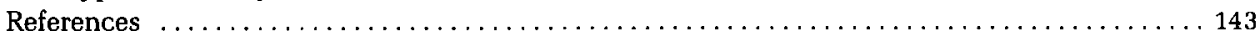

\section{Taxonomy of Galápagos Brachyura}

\subsection{Introduction}

This chapter constitutes an update of my "Littoral brachyuran fauna of the Galápagos Archipelago" (Garth, 1946a). Written 45 years ago, it dealt with a total of 120 species, 87 genera, and 15 families of "short-tailed" crabs, of which 44 species, 32 genera, and five families were reported for the first time from the Galápagos, largely as the result of five Hancock Expeditions (1932, 1933, 1934, 1935, and 1938) of which I was a member. Although I have not returned to the islands meanwhile, I have reviewed two important Galápagos collections: one made by Victor A. Zullo, resident systematist, Marine Biological Laboratory, Woods Hole, Massachusetts, in January-February 1964, as a member of GISP (Galápagos International Scientific Program]; the other by Gerard M. Wellington [University of Houston, Houston, Texas (formerly Charles Darwin Research Station, Isla Santa Cruz, Galápagos, from November 1973 to August 1975)], while laying the groundwork for the establishment of a marine national park (Wellington, 1976). As a result of these collections, generously donated to the Allan Hancock Foundation (AHF), eight species and four genera were added to the insular fauna.

Of importance equal to the discovery of species and genera of brachyurans new to the Galápagos Islands was the rediscovery, in the University Museum, Oxford,

JOHN S. GARTH - Allan Hancock Foundation, University of Southern California, Los Angeles, 
England, of Bell's lost types (DiMauro, 1982). Among them were syntypes of Herbstia edwardsii, Thoe erosa, Pisoides edwardsii, Microphrys aculeatus, Mithrax ursus (= Mithrax bellii Gerstaecker, 1857), Mithrax nodosus, Mithrax denticulatus, Pitho sexdentata, Pericera (= Stenocionops) ovata (all Bell, 1835); Persephona edwardsii and Leucosilia jurinei (both Bell, 1855). All were collected by Hugh Cuming, and were attributed to the Galápagos Islands. Because Zullo and Wellington failed to find eight of the ten species described by Bell $(1835,1855)$, as had Hancock and other expeditions before them, it was agreed (by Wellington and the writer, in correspondence) that they should be dropped from the Galápagos list, leaving it, as before, at 120 species. Corrected type localities for several species of spider crabs were given in my monograph on Pacific American Oxyrhyncha (Garth, 1958).

The Spedizione Lodovico Mares-G.R.S.T.S. (Gruppo Ricerche Scientifiche e Tecniche Subacquee, Florence, Italy) to the Galápagos Islands (December 1971 to January 1972) assembled a small but interesting collection of decapod Crustacea. Included were a dozen species of Brachyura, all of them previously reported. This material is preserved in the collections of the Museo Zoologico del-l'Universita, Florence (MF), with duplicate specimens in the Rijksmuseum van Natuurlijke Historie, Leiden, The Netherlands (RMNH) (Holthuis, 1979).

Although the number of species of brachyuran crabs found in the Galápagos remains the same, the number of genera has increased phenomenally. This is due to the tendency among taxonomists to break up, or "split," the larger genera into smaller ones. Such has been the fate of the older, more inclusive genera of Xanthidae: in particular, Actaea, Medaeus, Micropanope, and Pilumnus, well represented in the Galápagos. At least seven genera have been added to the Galápagos fauna as a result of such proliferation. These, when added to the genera of newly discovered species, which total four, make eleven genera to be added to the earlier list; however, the deletion of the eight species described by Bell, but not since found in the Galápagos, requires the deletion of several genera as well. The list (Table 1) now numbers 120 species, 91 genera, and 15 families of brachyuran crabs. Table 2 lists name changes, additions, and deletions from the original list.

Two additional changes have been proposed that affect the Galápagos brachyuran fauna. The oxystomatous genus Osachila, represented in the archipelago by $O$. levis and $O$. galapagensis, has been transferred from the family Calappidae to the family Parthenopidae (Guinot, 1966, p. 841). The genus Daira, represented in the islands by $D$. americana, also has been transferred to the Parthenopidae (Guinot, 1967b, p. 550), but on more tenuous grounds. I, therefore, follow Sakai (1976, p. 550) in considering Daira a xanthid of uncertain status.

Of the species marked "genus incertae sedis," Actaea angusta is insufficiently known to have been included in any of the smaller genera into which the old genus Actaea was partitioned (Guinot, 1976, p. 204). Like Micropanope fraseri and Paraxanthias insculptus, it remains without an acceptable generic assignment. Lophopanopeus maculatus was eliminated from that genus by Menzies (1948, p. $24)$, with the suggestion that it might be accommodated in Micropanope. As presently restricted (Guinot, 1967a, p. 349), Micropanope contains only its type species and one other. In such cases, the old generic name is used in quotation marks, as evidence of its unsuitability.

My unpublished studies on Gulf of California spider crabs will show that I was 
Table 1. Distribution of Galápagos Brachyura ${ }^{a}$

垔

Family Raninidae

Notosceles ecuadorensis (Rathbun 1935)

Ranilia fornicata (Faxon 1893)

Family Dromiidae

Dromidia larraburei Rathbun 1910

Hypoconcha panamensis Smith 1869

Family Dynomenidae

Dynomene ursula Stimpson 1860

Family Dorippidae

Ethusa lata Rathbun 1893

Clythrocerus Iaminatus Rathbun 1935

Family Leucosiidae

Ebalia hancocki Rathbun 1933

Lithadia cumingii Bell 1855

Uhlias ellipticus Stimpson 1871

Leucosia jurinei (Saussure 1853)

Randallia agaricias Rathbun 1898

Family Calappidae

Calappa convexa Saussure 1853

Mursia gaudichaudii (Milne Edwards 1837)

Cycloes bairdii Stimpson 1860

Family Majidae

Stenorhynchus debilis Smith 1871

Anomalothir hoodensis Garth 1939

Podochela margaritaria Rathbun 1902

Podochela schmitti Garth 1939

Euprognatha granulata Faxon 1893

Acanthonyx petiverii Milne Edwards 1834

Eupleurodon rathbunae Garth 1939

Eupleurodon trifurcatus Stimpson 1871

Taliepus margnatus (Bell 1835)

Sphenocarcinus agassizi Rathbun 1893

Herbstia edwardsii Bell 1835

Herbstia pyriformis (Bell 1835]

Lissa aurivilliusi Rathbun 1898

Pitho quinquedentata Bell 1835

Pitho sexdentata Bell 1835

Mithrax spinipes (Bell 1835)

Mithrax mexicanus Glassell 1936

(Clarion)

\section{$\mathbf{x}$}

$\mathbf{X}$

$\mathrm{X}$

$\mathbf{X}$

$\mathbf{X}$

$\mathbf{x}$

$\mathbf{X}$

[Socorro]

$\begin{array}{cc} & x \\ & \\ & x \\ & \\ & \\ & \\ & \\ & \\ & \\ & \\ & \\ x \\ x \\ \text { (Cocos) }\end{array}$

$\mathrm{x}$

Mithrax belli Gerstaecker 1856

Mithrax pygmaeus Bell 1835

Mithrax nodosus Bell

Teleophrys cristulipes Stimpson 1860

Stenocionops triangulata (Rathbun 1892)
EP

AT

AT

AT

EP

AT

$\mathrm{EP}$

EP

AT

AT

EP

EP

AT

WP

AT

AT

AT

EP

EP

EP

AT

EP

EP

EP

AT

EP

EP

AT

AT

AT

AT

EP

AT

EP

EP

AT

AT 
Table 1. (continued)

\begin{tabular}{|c|c|c|c|c|c|c|c|}
\hline & 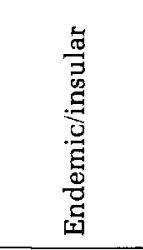 & 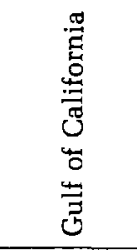 & 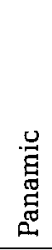 & 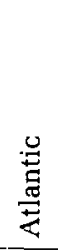 & 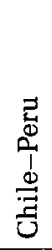 & 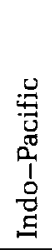 & 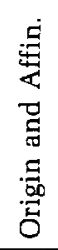 \\
\hline Microphrys aculeatus (Bell 1835) & & & & & $\mathrm{x}$ & & $\mathrm{EP}$ \\
\hline Microphrys trangulatus (Lockington 1876) & & $\mathrm{x}$ & $\mathrm{x}$ & & & & EP \\
\hline Microphrys platysoma (Stimpson 1860) & & $\mathrm{x}$ & $\mathrm{x}$ & an & & & AT \\
\hline Tyche galapagensis Garth 1958 & $\mathrm{x}$ & & & & & & EP \\
\hline \multicolumn{8}{|l|}{ Family Parthenopidae } \\
\hline Parthenope exilipes (Rathbun 1893) & & $\mathrm{x}$ & $\mathrm{x}$ & an & & & AT \\
\hline Parthenope triangula (Stimpson 1860) & (La Plata) & $\mathrm{x}$ & & & & & WP \\
\hline Daldorfia garthi Glassell 1940 & & $\mathrm{x}$ & $\mathrm{x}$ & & & & WP \\
\hline Solenolambrus arcuatus Stimpson 1871 & & $\mathrm{x}$ & $\mathrm{x}$ & an & & & $\mathrm{AT}$ \\
\hline Mesorhoea bellii (A. Milne Edwards 1878) & & $\mathrm{x}$ & $\mathrm{x}$ & an & & & $\mathrm{AT}$ \\
\hline Aethra scruposa scutata Smith 1869 & & $x$ & & & & & WP \\
\hline Osachila galapagensis Rathbun 1935 & $\mathbf{x}$ & & & & & & $\mathrm{EP}$ \\
\hline Osachila levis Rathbun 1898 & & $\mathrm{x}$ & $\mathbf{x}$ & & & & EP \\
\hline \multicolumn{8}{|l|}{ Family Portunidae } \\
\hline Portunus stanfordi Rathbun 1902 & $\mathbf{x}$ & & & & & & EP \\
\hline Portunus angustus Rathbun 1898 & $x$ & & & an & & & AT \\
\hline Portunus tuberculatus (Stimpson 1860) & & $\mathrm{x}$ & $\mathrm{x}$ & & & & EP \\
\hline Callinectes arcuatus Ordway 1863 & & $\mathrm{x}$ & $\mathrm{x}$ & an & & & AT \\
\hline Callinectes toxotes Ordway 1863 & & $\mathrm{x}$ & $\mathrm{x}$ & an & & & AT \\
\hline Cronius ruber (Lamarck 1818) & & $\mathrm{x}$ & $\mathrm{x}$ & $\mathrm{x}$ & $\mathrm{x}$ & & AT \\
\hline Euphylax dovii Stimpson 1860 & & & $\mathrm{x}$ & & $\mathrm{x}$ & & WP \\
\hline \multicolumn{8}{|l|}{ Family Atelecyclidae } \\
\hline Kraussia americana Garth 1939 & & $x$ & $\mathrm{x}$ & & & & WP \\
\hline \multicolumn{8}{|l|}{ Family Xanthidae } \\
\hline Liomera cinctimana (White 1847) & & $\mathbf{x}$ & $\mathrm{x}$ & & & $\mathrm{x}$ & WP \\
\hline Platypodiella gemmata (Rathbun 1902) & & & $x$ & & & & $\mathrm{EP}$ \\
\hline Platypodiella rotundata (Stimpson 1860) & & $\mathbf{x}$ & $x$ & an & & & AT \\
\hline Platyactaea dovii (Stimpson 1871) & & $\mathbf{x}$ & $x$ & an & & & AT \\
\hline Paractaea sulcata (Stimpson 1860) & & $x$ & $\mathbf{x}$ & an & & & AT \\
\hline "Actaea" angusta Rathbun 1898 & $\mathrm{x}$ & & & an & & & AT \\
\hline Glyptoxanthus hancocki Garth 1939 & $\mathrm{x}$ & & & & & & EP \\
\hline Daira americana Stinpson 1860 & & $x$ & $x$ & & & & WP \\
\hline Lipaesthesius leeanas Rathbun 1898 & & $x$ & $\mathrm{x}$ & & & & $\mathrm{EP}$ \\
\hline Edwardsium crosslandi (Finnegan 1931) & $\mathrm{x}$ & & & & & & EP \\
\hline Edwardsium lobipes (Rathbun 1898) & & $\mathbf{x}$ & $\mathrm{x}$ & an & & & AT \\
\hline "Medaeus" spinulifer (Rathbun 1898) & & $\mathrm{x}$ & $\mathbf{x}$ & & & & EP \\
\hline Cycloxanthops vittatus (Stimpson 1860) & & $x$ & $x$ & & & & EP \\
\hline $\begin{array}{l}\text { Cataleptodius occidentalis (Stimpson } \\
\text { 1871) }\end{array}$ & & $x$ & & an & & & AT \\
\hline Cataleptodius snodgrassi (Rathbun 1902) & $\mathrm{x}$ & & & & & & EP \\
\hline Xanthodius cooksoni (Miers 1877) & $\mathrm{x}$ & $\begin{array}{l}\text { (Clarion) } \\
\text { (Socorro) }\end{array}$ & & an & & & AT \\
\hline $\begin{array}{l}\text { Lophoxanthus lamellipes (Stimpson } \\
\text { 1860) }\end{array}$ & & $\mathrm{x}$ & $\mathbf{x}$ & & & & EP \\
\hline $\begin{array}{l}\text { "Lophopanopeus" maculatus Rathbun } \\
1898\end{array}$ & & $\mathbf{x}$ & $\mathrm{x}$ & & & & EP \\
\hline
\end{tabular}


Table 1. (continued)

\begin{tabular}{|c|c|c|c|c|c|c|c|}
\hline & 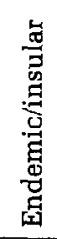 & 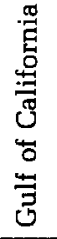 & 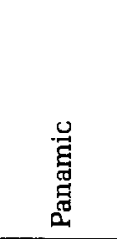 & 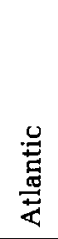 & 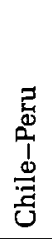 & 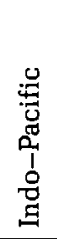 & 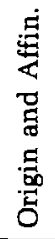 \\
\hline $\begin{array}{l}\text { Eurypanopeus transversus (Stimpson } \\
\text { 1860) }\end{array}$ & & & $\mathbf{x}$ & & $\mathbf{x}$ & & $\mathrm{EP}$ \\
\hline Hexapanopeus cartagoensis Garth 1939 & $\mathbf{x}$ & & & & & & EP \\
\hline Eurytium affine (Streets \& Kingsley 1877) & & $\mathrm{x}$ & & & & & EP \\
\hline Microcassiope xantusii (Stimpson 1871) & & $\mathrm{x}$ & $\mathrm{x}$ & an & & & AT \\
\hline Nanocassiope polita (Rathbun 1893) & & $\mathrm{x}$ & (Cocos) & an & & & AT \\
\hline "Micropanope" fraseri Garth 1946 & $\mathrm{x}$ & & & & & & EP \\
\hline Tetraxanthus rathbunae Chase 1940 & & & & $x$ & & & AT \\
\hline Ectaesthesius bifrons Rathbun 1898 & $\mathrm{x}$ & & & & & & EP \\
\hline $\begin{array}{l}\text { "Paraxanthias" insculptus (Stimpson } \\
\text { 1871) }\end{array}$ & & $\mathrm{x}$ & & & & & EP \\
\hline Menippe obtusa Stimpson 1860 & & & $\mathbf{x}$ & & & & EP \\
\hline Globopilumnus xantusii (Stimpson 1860) & & $\mathbf{x}$ & $\mathrm{x}$ & & & & EP \\
\hline Pilumnus pygmaeus Boone 1927 & & $x$ & $\mathbf{x}$ & & & & EP \\
\hline Acidops fimbriatus Stimpson 1871 & & $x$ & & & & & WP \\
\hline Ozius verreauxii Saussure 1853 & & & $\mathbf{x}$ & & & & EP \\
\hline Ozius perlatus Stimpson 1860 & & $\mathrm{x}$ & $\mathrm{x}$ & an & & & AT \\
\hline $\begin{array}{l}\text { Epixanthus tenuidactylus (Lockington } \\
\text { 1877) }\end{array}$ & & $x$ & $\mathrm{x}$ & & & & EP \\
\hline Eriphia squamata Stimpson 1859 & & $\mathrm{x}$ & $\mathrm{x}$ & an & & & AT \\
\hline Eriphia granulosa A. Milne Edwards 1880 & $\mathbf{x}$ & & & & & & EP \\
\hline Eriphides hispida (Stimpson 1860) & & $\mathrm{x}$ & & & & & EP \\
\hline $\begin{array}{l}\text { Domecia hispida Eydoux and Souleyet } \\
1842\end{array}$ & & $\mathrm{x}$ & $\mathbf{x}$ & & & $x$ & WP \\
\hline Trapezia ferruginea Latreille 1825 & & $\mathrm{x}$ & $\mathrm{x}$ & & & $\mathrm{x}$ & WP \\
\hline Trapezia digitalis Latreille 1825 & & $\mathrm{x}$ & $\mathrm{x}$ & & & $\mathrm{x}$ & WP \\
\hline Quadrella nitida Smith 1869 & & $\mathrm{x}$ & $\mathrm{x}$ & & & & WP \\
\hline Jonesius triunguiculatus (Borradaile 1903) & & & $\mathrm{x}$ & & & $\mathrm{x}$ & WP \\
\hline \multicolumn{8}{|l|}{ Family Pinnotheridae } \\
\hline Parapinnixa glasselli Garth 1939 & $\mathrm{x}$ & & & & & & $\mathrm{EP}$ \\
\hline $\begin{array}{l}\text { Pinnixa transversalis (Milne Edwards and } \\
\text { Lucas 1843) }\end{array}$ & & $\mathrm{x}$ & $\mathrm{x}$ & an & & & AT \\
\hline Pinnixa darwini Garth 1960 & $\mathrm{x}$ & & & an & & & AT \\
\hline $\begin{array}{l}\text { Pinnaxodes chilensis (Milne Edwards } \\
\text { 1837) }\end{array}$ & & & & & $\mathrm{x}$ & & EP \\
\hline Pinnotheres aff. pubescens (Holmes 1900) & & $\mathrm{x}$ & & & & & $\mathrm{EP}$ \\
\hline \multicolumn{8}{|l|}{ Family Palicidae } \\
\hline Palicus cortezi (Crane 1937) & & $\mathbf{x}$ & & & & & EP \\
\hline Palicus fragilis (Rathbun 1893) & & $\mathbf{x}$ & $\mathrm{x}$ & & & & EP \\
\hline Palicus velerae (Garth 1939) & $\mathrm{x}$ & & & & & & EP \\
\hline Palicus lucasii Rathbun 1893 & & $\mathrm{x}$ & $\mathrm{x}$ & an & & & AT \\
\hline \multicolumn{8}{|l|}{ Family Grapsidae } \\
\hline Grapsus grapsus (Linnaeus 1758) & & $\mathrm{x}$ & $\mathrm{x}$ & $\mathrm{x}$ & & & AT \\
\hline Geograpsus lividus (Milne Edwards 1837) & & $\mathbf{x}$ & $\mathrm{x}$ & $\mathrm{x}$ & & & $\mathrm{AT}$ \\
\hline Pachygrapsus transversus (Gibbes 1850) & & $\mathbf{x}$ & $\mathbf{x}$ & $\mathbf{x}$ & $\mathbf{x}$ & & AT \\
\hline Planes cyaneus Dana 1852 & & $\mathbf{x}$ & $x$ & & & $\mathbf{x}$ & WP \\
\hline Euchirograpsus pacificus Türkay 1975 & $\mathrm{x}$ & & & an & & & AT \\
\hline
\end{tabular}


Table 1. (continued)

\begin{tabular}{|c|c|c|c|c|c|c|c|c|c|}
\hline & & & 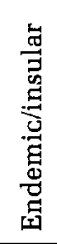 & 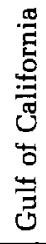 & 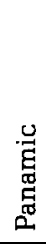 & 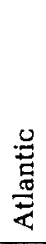 & 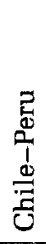 & 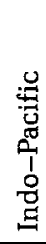 & 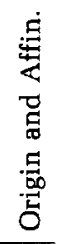 \\
\hline \multicolumn{3}{|c|}{ Plagusia immaculata Lamarck 1818} & & & $\mathbf{x}$ & & & $\mathrm{x}$ & WP \\
\hline \multicolumn{3}{|c|}{ Percnon gibbesi (Milne Edwards 1853) } & & $\mathrm{x}$ & $\mathrm{x}$ & $\mathrm{x}$ & $\mathrm{x}$ & & AT \\
\hline \multicolumn{10}{|c|}{ Family Ocypodidae } \\
\hline \multicolumn{3}{|c|}{$\begin{array}{l}\text { Ocypode gaudichaudii Milne Edwards } \\
\text { and Lucas } 1843\end{array}$} & & & $\mathrm{x}$ & & $\mathrm{x}$ & & $\mathrm{EP}$ \\
\hline \multicolumn{3}{|c|}{ Uca galapagensis Rathbun 1902} & $\mathrm{x}$ & & & & & & EP \\
\hline \multicolumn{3}{|c|}{ Uca helleri Rathbun 1902} & $\mathrm{x}$ & & & & & & EP \\
\hline \multicolumn{10}{|c|}{ Family Cryptochiridae } \\
\hline \multicolumn{3}{|c|}{$\begin{array}{l}\text { Hapalocarcinus marsupialis Stimpson } \\
1858\end{array}$} & & & $x$ & & & $\mathrm{x}$ & WP \\
\hline \multicolumn{3}{|c|}{$\begin{array}{l}\text { Pseudocryptochirus crescentus } \\
\text { (Edmondson 1933) }\end{array}$} & & $x$ & & & & $\mathrm{x}$ & WP \\
\hline \multirow{5}{*}{$\begin{array}{l}\text { aEP-Eastern Pacific } \\
\text { WP-Western Pacific } \\
\text { AT-Atlantic } \\
\text { an-Analogue }\end{array}$} & No. & $\%$ & & & & & & & \\
\hline & 55 & 45.8 & & & & & & & \\
\hline & 18 & 15.0 & & & & & & & \\
\hline & 8 & 6.6 & & & & & & & \\
\hline & $\frac{39}{120}$ & $\frac{32.4}{99.8}$ & & & & & & & \\
\hline
\end{tabular}

spinipes (Bell, 1835), and that the former is a valid species. Reexamination of Galápagos material of $M$. spinipes in Hancock collections shows that all are $M$. mexicanus instead. As Bell's material was from two localities, Galápagos, 16 fathoms, and Santa Elena, 6 fathoms, the question arises: is not $M$. spinipes another mainland species wrongly attributed to the Galápagos? And, like others of Cuming's collecting, should it be attributed to the mainland alone? A subsequent paper will address these questions.

Working with material collected form corals at Gorgona Island, Colombia, Castro (1982) raised from synonymy the names Trapezia corallina Gerstaecker, 1857 and T. formosa Smith, 1869. Although he recognized these among Hancock material of Trapezia, there was a residue of unidentifiable specimens, owing to loss of color. Until fresh material becomes available, and pending studies underway by Bella Galil (pers. comm.), I continue to recognize only two species, T. ferruginea and $T$. digitalis, from Galápagos waters.

\subsection{New Records since 1946}

\subsubsection{New to the Galápagos Islands}

Eupleurodon trifurcatus Stimpson, Caleta Iguana, Isla Isabela, from Corallina pinnatifolius just below low water line, December 6, 1974, 1우 4 क (3 ov), G.M. Wellington, collector (B-130). 
Table 2. List of Name Changes, Additions, and Deletions

\begin{tabular}{|c|c|c|}
\hline Garth, 1946 & Changed to, or deleted & Authority \\
\hline \multicolumn{3}{|l|}{ Family Raninidae } \\
\hline Raninoides ecuadorensis Rathbun & Notosceles ecuadorensis (Rathbun) & Goeke, 1981 \\
\hline \multicolumn{3}{|l|}{ Family Leucosiidae } \\
\hline Persephona edwardsii Bell & (delete) & Garth, 1991 \\
\hline \multicolumn{3}{|l|}{ Family Majidae } \\
\hline Dasygyius depressus (Bell) & (delete) Paradasygyius depressus (Bell) & Garth, 1958 \\
\hline Dasygyius gibbosus (Bell) & (delete) Collodes gibbosus (Bell) & Garth, 1958 \\
\hline Pelia pulchella Bell & (delete) & Garth, 1991 \\
\hline Pisoides edwardsii (Bell) & (delete) & Garth, 1958 \\
\hline Thoe erosa Bell & (delete) & Garth, 1991 \\
\hline Mithrax denticulatus Bell & (delete) & Garth, 1958 \\
\hline Mithrax spinipes (Garth, not Bell) & Mithrax mexicanus Glassell & Garth, MS \\
\hline Stenocionops ovata (Bell) & (delete) & Garth, 1991 \\
\hline Tyche Iamellifrons Bell & Tyche galapagensis Garth & Garth, 1958 \\
\hline \multicolumn{3}{|l|}{ Family Xanthidae } \\
\hline Carpilodes cinctimanus (White) & Liomera cinctimana (White) & $\begin{array}{l}\text { Forest and } \\
\text { Guinot, } 1961\end{array}$ \\
\hline Platypodia gemmata Rathbun & Platypodiella gemmata (Rathbun) & Guinot, 1967b \\
\hline Platypodia rotundata (Stimpson) & Platypodiella rotundata (Stimpson) & Guinot, 1967b \\
\hline Actaea dovii Stimpson & Platyactaea dovii (Stimpson) & Guinot, $1967 \mathrm{~b}$ \\
\hline Actaea angusta Rathbun & Genus incertae sedis & Guinot, 1976 \\
\hline Actaea sulcata Stimpson & Paractaea sulcata (Stimpson) & Guinot, $1969 \mathrm{~b}$ \\
\hline Actaea crosslandi (Finnegan) & Edwardsium crosslandi (Finnegan) & Guinot, 1967a,b \\
\hline Medaeus lobipes Rathbun & Edwardsium Iobipes (Rathbun) & Guinot, 1967a,b \\
\hline Medaeus spinulifer (Rathbun) & Genus incertae sedis & Guinot, 1971 \\
\hline Leptodius occidentalis (Stimpson) & Cataleptodius occidentalis (Stimpson) & Guinot, 1968 \\
\hline Leptodius snodgrassi Rathbun & Cateleptodius snodgrassi (Rathbun) & Guinot, 1968 \\
\hline Leptodius cooksoni Miers & Xanthodius cooksoni (Miers) & Guinot, 1968 \\
\hline Lophopanopeus maculatus Rathbun & Genus incertae sedis & Menzies, 1948 \\
\hline Micropanope xantusii (Stimpson) & Microcassiope xantusii (Stimpson) & Guinot, 1967a \\
\hline Micropanope polita Rathbun & Nanocassiope polita (Rathbun) & Guinot, $1967 \mathrm{a}$ \\
\hline Micropanope fraseri Garth & Genus incertae sedis & Guinot, 1967a \\
\hline Paraxanthias insculptus (Stimpson) & Genus incertae sedis & Guinot, 1968 \\
\hline Pilumnus xantusii Stimpson & Globopilumnus xantusii (Stimpson) & Garth, 1968 \\
\hline Ozius tenuidactylus (Lockington) & Epixanthus tenuidactylus (Lockington) & Monod, 1956 \\
\hline Maldivia galapagensis Garth & Jonesius triunguiculatus (Borradaile) & $\begin{array}{l}\text { Galil and Takeda, } \\
1986\end{array}$ \\
\hline \multicolumn{3}{|l|}{ Family Grapsidae } \\
\hline $\begin{array}{l}\text { Euchirograpsus americanus } \\
\text { A. Milne Edwards }\end{array}$ & Euchirograpsus pacificus Türkay & Türkay, 1975 \\
\hline Family Cymopoliidae & Family Palicidae & $\begin{array}{l}\text { Holthuis and } \\
\text { Gottlieb, } 1958\end{array}$ \\
\hline Cymopolia fragilis Rathbun & Palicus fragilis (Rathbun) & Garth, 1991 \\
\hline Cymopolia cortezi Crane & Palicus cortezi (Crane) & Garth, 1991 \\
\hline Cymoplia velerae Garth & Palicus velerae (Garth) & Garth, 1991 \\
\hline Cymopolia lucasii (Rathbun) & Palicus lucasii (Rathbun) & Garth, 1991 \\
\hline
\end{tabular}


The genus Eupleurodon was established by Stimpson $(1971$, p. 98) for the then unique species, E. trifurcatus, of which the female holotype, no longer extant, was collected by John Xantus at Cabo San Lucas, Baja California. Two species have been added since that date: E. rathbunae Garth (1939, p. 13), collected by Velero III at Gardner Bay, Hood Island (Isla Española), Galápagos, of which the unique holotype was also a female; and E. peruvianus (Rathbun, 1910, p. 535), transferred from Epialtus by Garth (1958, p. 243), of which the male holotype was collected by R. C. Murphy at Chinchas Islands, Peru. Because two of the three species were known from the female sex only, it was impossible to say, in the absence of males, whether E. rathbunae was distinct from $E$. trifurcatus. The discovery by Gerard Wellington of males of two types that can be matched with females of $E$. rathbunae and $E$. trifurcatus, respectively, supports the view that they are indeed separate species, and that both occur in the Galápagos Islands.

Callinectes arcuatus Ordway, S. Channel, Isla Santa Cruz, campsite, February $12,1964,1$ ㅇ, V. A. Zullo, collector (Z-336); Turtle Cove, Isla Santa Cruz, February 14, 1964, 1 ygô , C. Angemeyer, collector (Z-341).

Callinectes toxotes Ordway, Villamil, Isla Isabela, from tidal lagoon in mangrove area, April 15, 1975, 10, G. M. Wellington, collector (B-147).

Swimming crabs of the genus Callinectes were not encountered in the Galápagos by Hancock or earlier expeditions. The male C. arcuatus found by Victor A. Zullo while a member of the Galápagos International Scientific Project (GISP) was reported by Garth and Stephenson (1966). The female C. toxotes found by Gerard M. Wellington is here reported for the first time.

Pinnotheres cf. pubescens Holmes, Caleta Iguana, Isla Isabela, internal parasite of Lytechinus semituberculatus, April 15, 1975, 4 , G. M. Wellington, collector (B-149).

Although the pinnotherid specimens above compare well enough with the original description and illustration of P. pubescens, described by S. J. Holmes from the Gulf of California (Holmes, 1900), no specimen comparison is possible, as the type no longer exists. Also, according to F. C. Ziesenhenne (pers. comm.), a different species of Lytechinus occurs in the Gulf of California, L. semituberculatus being a Galápagos endemic. It therefore seems best to keep a little taxonomic distance between the two until specimens from the Gulf of California are found.

Hapalocarcinus marsupialis Stimpson, Academy Bay, Isla Santa Cruz, April 24, 1975, from Pocillopora coral, G. M. Wellington, collector.

The coral gall crab was considered an Indo-Pacific species until discovered at Port Utria, Colombia, by Velero III collectors, on January 23, 1935, as reported by Schmitt (1936). It is also known from Clipperton Island (Garth, 1965).

Pseudocryptochirus crescentus (Edmondson), seen by G. M. Wellington.

This species is included in the Galápagos fauna on the assurance of Dr. Wellington that he has seen its characteristic burrows in Pavona coral (letter of 28 May 1975). The species has been reported from Clipperton (Garth, 1965), and the Gulf of California (Garth and Hopkins, 1968).

\subsubsection{New to Islands within the Group}

To Isla Fernandina, Punta Espinosa: June 24, 1974, G. M. Wellington, 
(Bell), $1 \delta$ (B-110); Podochela margaritaria Rathbun, 1ठ, 19 ov (B-111): "Micropanope" fraseri Garth, 10 (B-112), 1 (B-113); Eurytium affine (Streets and Kingsley), $1 \delta^{7}$ (B-114); July 25, 1938, W. L. Schmitt, collector, Ozius verreauxii Saussure, 19, Sta. 16-38.

The Velero III established but a single station on Isla Fernandina on January 14, 1934, at which Mithrax nodosus, Xanthodius cooksoni, Leptodius snodgrassi, Epixanthus tenuidactylus, Geograpsus lividus, and Uca helleri were encountered. In revisiting the site on July 25, 1938, as a member of the Presidential Cruise aboard the U.S.S. Houston, W. L. Schmitt added Ozius verreauxii, but failed to include it in his report of that expedition (Schmitt, 1939). The specimen came to me among unidentified Xanthidae sent to me by the Smithsonian Institution as part of its AEC/ONR Project of the early 1960's. The importance of these records, and of those of G. M. Wellington, above, is that Isla Fernandina is the most northwesterly of the island group (excluding outliers), and, together with the adjacent northwest coast of Isla Isabela, is immersed in cold water.

To Isla Isabela, Caleta Iguana: Eupleurodon rathbunae Garth, from branches of Amphiroa dimorpha, $3 \mathrm{~m}$, December 6, 1974,10; on Corallina pinnatifolia, April 15, 1975, 1 megalopa (B-148), G. M. Wellington, collector.

To Isla Genovesa: Nanocassiope polita (Rathbun), 20-30 fms, January 19, 1975, 3 đ , 2 \% ov (B-132), G. M. Wellington, collector.

To Isla Champion, Isla Santa Maria: Eupleurodon rathbunae Garth, February 27, 1974, from branches of Amphiroa dimorpha, $3 \mathrm{~m}, 1$ specimen, G. M. Wellington, collector.

To Isla Española, Punta Suarez: Planes cyaneus Dana, June 24, 1974, 1 ๙ (B-115), G. M. Wellington, collector.

\subsubsection{Otherwise Noteworthy}

"Actaea" angusta Rathbun, Isla Floreana, NW of Isla Onslow, $20 \mathrm{fms}$, nullipore coral, January 13, 1975, 1 \% (B-117), G. M. Wellington, collector.

Known previously only from the holotype, a female collected off Isla Española in $20 \mathrm{fms}$ by the Albatross in 1888, and from a young female collected off Gardner Bay, Isla Española, in 25-35 fms by the Velero III in 1935, this distinctive species is destined to remain a rarity in collections. The male of the species is unknown.

Platypodiella rotundata (Stimpson), Academy Bay, Isla Santa Cruz, November 29, 1974, 1 i (B-128), G. M. Wellington, collector.

Although the extensive series of Platypodiella obtained by Velero III collectors was reported as the endemic P. gemmata by Garth (1946a), the finding by Wellington, as had Crossland before him (Finnegan, 1931), of a specimen clearly referable to the mainland $P$. rotundata, lends credence to the possibility that the two are one species, $P$. gemmata being the young of $P$. rotundata, and hence not a Galápagos endemic, as heretofore supposed.

Uca galapagensis Rathbun, Punta Cormorant, Isla Floreana, February 26, 1974, 19 (B-117), G. M. Wellington, collector.

Uca helleri Rathbun, Academy Bay, Isla Santa Cruz, April 7, 1974, $30^{\star}, 2 q$ (B-118), G. M. Wellington, collector.

As the Galápagos Islands become increasingly populated, particularly at Academy Bay, which houses a sizeable community, but also near Punta Cor- 
fiddler crabs, which take alarm at the slightest intrusion, face increasing pressure. It is therefore reassuring to know that, as of 1974 , these two colonies were holding up well.

\section{Distribution of Galápagos Brachyura}

\subsection{Introduction}

Since my Distribution Studies of Galápagos Brachyura was completed (Garth, 1946b), knowledge of natural phenomena in the surrounding region has increased greatly. Plate tectonics, submerged seamounts, sub-surface currents (i.e., the Cromwell Current), then unknown, may be mentioned; in addition, the El Niño phenomenon is recognized not as a local event emanating from the Bay of Panama, but as a hemispheric event, originating in the western Pacific and influencing climate as far north as California and as far south as Chile. The oceanic transport of planktonic larvae of many invertebrates has been well documented, and the geological age of the islands is known with greater certainty. As a result of these developments, and of the finer tuning of the systematic relationships of the crabs themselves, their intra- and extra-Galápagan distributions can be reexamined now with more assurance.

\subsection{Changes in Distributional Status}

From time to time Galápagos material in Hancock collections has been sent to carcinologists intent on revising genera or larger groups on a world-wide basis. This permits Galápagos specimens to be compared with the same species, or with related species, from distant parts of the globe. The decisions reached by these specialists often reveal relationships unsuspected from studying the insular fauna in isolation. For example, a Galápagos specimen identified by me as Euchirograpsus americanus A. Milne Edwards 1880, sent to Michael Türkay for examination, was returned as the holotype of E. pacificus n. sp. (Türkay, 1975), when it proved possible to separate it from the west Atlantic species. Similarly, the Tetraxanthus reported by Garth $(1946 a$, p. 465$)$ as T. rathbunae Chace, an Atlantic species, on the basis of a single female, is likely, when males are known, to prove distinct from that species. In making critical species distinctions, the male first pleopod is essential.

Specimens of Domecia hispida sent to Danièle Guinot enabled her to verify the identity of eastern and western Pacific material of this species (Guinot, 1964), and to revive, for western Atlantic material formerly referred to D. hispida, the name D. acanthophora Desbonne (in Desbonne and Schramm, 1867). Previously considered to occur on both sides of the Isthmus of Panama, D. hispida now becomes a Pacific species with an Atlantic analogue. Maldivia galapagensis Garth 1939 was shown by Galil and Takeda (1986) to be identical with $M$. triunguiculatus Borradaile 1903, and the generic name Jonesius Sankarankutty 
1962 applied. J. triunguiculatus, therefore, joins other coral-inhabiting species common to both western and eastern Pacific, and Galápagos consequently loses a presumed endemic species.

\subsection{Intra-Galápagan Distribution}

In my distribution studies (Garth, 1946b), a group of species, consisting of Palicus fragilis, P. cortezi, Microphrys platysoma, and Globopilumnus xantusii, was listed as found only at the extreme northerly islands of Wolf, Genovesa, and the northern part of Isabela (Tagus Cove, Albemarle Point) and Santiago (Sulivan Bay), while Eurytium affine was found on the north shore of Santa Cruz (Conway Bay). Similarly, Eupleurodon rathbunae and Microphrys aculeatus were mentioned as found only at the extreme southeasterly islands of Santa Maria and Española. The northern group was said to have affinities with the Gulf of California, while the latter group was said to be related to the Chile-Peru fauna. The implication was that the northerly group of species, after arriving at the northernmost islands from the Gulf of California-Baja California region via the California and Panama currents, were unable to disperse further southward within the Galápagos Islands, while the southerly group of species, carried from Peru and Chile by the Peru Current, were likewise unable to advance further northward. The configuration of ocean currents within the islands was considered as barring further penetration.

Additional material collected by Gerard Wellington from both northerly (Fernandina) and southerly (Española) islands provides an opportunity to test these speculations. Apparently, the one that holds up is that the northwesterly islands are inhabited by cold-water species of crabs (and shrimps), as they are by penguins and flightless cormorants. In a letter dated August 21, 1975, Wellington wrote: "[I have] just received word from Dr. [Fenner A.] Chace that the shrimp [from Caleta Iguana] is very probably Rhynchocinetes typus, previously known only from Peru and Chile and Juan Fernandez (a cool water species). In Galápagos it is restricted to Fernandina and western Isabela. This information adds further evidence to my contention that this western region forms a separate faunal-floral province in the islands." The Microphrys species found by Wellington at Punta Espinosa, Isla Fernandina, was M. aculeatus, the Peru-Chile species.

The Gulf of California is recognized as belonging to the warm-water Panamic province; it is named separately in Table 1. Any north-temperate species found in the Galápagos Islands would have had to come from Baja California north of Punta Eugenia, rather than from the Cabo San Lucas region, which is an island to warmwater species (see Garth, 1955). Further studies of islands off the coast of Mexico (Socorro, Clarion, Clipperton) have led to the category of insular endemic for species common to Galápagos and these offshore islands.

Finally, in a letter dated November 28, 1974, Gerard Wellington writes: "I suspect that the majority of species will eventually be found widely distributed in the archipelago. This past month I have been working in Academy Bay and have found that microhabitats play a major role in species abundance and distribution. I have found species, which were apparently absent in an area, abundant $100 \mathrm{~m}$ or less distance from the area I was sampling. The only difference between the two 
sites was somewhat looser rocks and a bit more sand. There is much work to be done in habitat descriptions before any statement can be made about interarchipelago distributions."

\subsubsection{Galápagos Endemic Species}

It is obvious that the $\mathbf{2 3}$ species found only in the Galápagos Islands to date cannot all be endemic: that is to say, having originated there and occurring nowhere else. Some, like Euchirograpsus pacificus and Anomalothir hoodensis, undoubtedly occur widely throughout the eastern Pacific, as do their counterpart species throughout the western Atlantic, but have not been collected elsewhere. Others, like Tyche galapagensis, are genuinely autochthonous, being represented on the mainland by $\mathrm{T}$. lamellifrons, to which Galápagos specimens were formerly referred, and in the Revillagigedo Islands, a northern hemispheric group, by $T$. clarionensis Garth, 1958. In the present state of our knowledge, however, we have no choice but to group them as endemics, pending clarification of their status by further collecting and taxonomic refinement.

Since 1946, when the presumed endemics were first listed, two additional species have been described that have been found in the Galápagos and nowhere else: the aforementioned Euchirograpsus pacificus by Türkay (1975) and Pinnixa darwini by Garth (1960). Both have Atlantic counterparts, the former in E. americanus A. Milne Edwards 1880, the latter in P. faxoni Rathbun 1913. This strongly suggests that the Galápagos species, or an as yet undescribed species having even closer affinities with the Atlantic one, should occur in the Bay of Panama, as the two oceans were recently confluent over the present Isthmus of Panama. One previous "endemic," the former Maldivia galapagensis, has been synonymized with $M$. triunguiculatus Borradaile 1903, a widely ranging Indo-west Pacific species, for which the name Jonesius Sankarankutty 1962 was revived by Galil and Takeda (1986), while Platypodiella gemmata, another presumed endemic, is now thought to represent the young of the mainland $P$. rotundata. Thus the list, although refined, still stands at 23 Galápagos endemic species (Table 1).

\subsection{Extra-Galápagan Distribution}

Because of their location at the convergence of three or more ocean currents, the Galápagos Islands share a portion of their brachyuran fauna with other regions, some adjacent, others remote. These are other islands in the eastern Pacific, the Gulf of California, the Bay of Panama, the western Atlantic, the western Pacific, and the Peru-Chile area. Because of the geologically recent Isthmian closure, ca. three million years ago, a special relationship exists with the Caribbean region, from which a current must formerly have flowed as well.

\subsubsection{Insular Endemic Species}

Other islands of the eastern Pacific share with the Galápagos a number of species that do not occur along adjacent mainland shores. Common to Clarion and Galápagos is Clythrocerus laminatus, to Socorro and Galápagos is Ebalia hancocki, 
and to both Clarion and Socorro is Xanthodius cooksoni. Common to Cocos and Galápagos are Euprognatha granulata, Microphrys triangulatus, and Nanocassiope polita, while common to these islands and to La Plata Island, Ecuador, is Parthenope triangula. These islands serve as stepping-stones in a broad arc extending from Cape San Lucas to Ecuador, touching the mainland only at its ends.

\subsubsection{Panamic Species}

The Panamic province, as broadly defined, stretches from the Gulf of California-Lower California to Ecuador. As might be expected from their location, on the Equator and 600 miles west of Ecuador, the Galápagos share with this faunistically rich province more species than with any other, a total of 63 , or more than half of its total fauna. A few, like Mursia gaudichaudii and Stenorhynchus debilis, exceed this range, extending from California to Chile; others, 15 in number, are restricted to the Bay of Panama alone. The Panama Current, which flows from the Bay of Panama toward the Galápagos from January to April, provides a way for larval stages to reach the islands on a regular basis, with recruitment from Mexico via the California Current only in exceptional years.

\subsubsection{Atlantic Species}

As time and taxonomy advance, fewer species are found in common between the eastern Pacific and western Atlantic. Of the seven mentioned in 1946, only five remain: Pachygrapsus transversus, Percnon gibbesi, Cycloes bairdii, Acanthonyx petiverii, and Cronius ruber. Euchirograpsus now has a Pacific, as well as an Atlantic species; Tetraxanthus rathbunae, an Atlantic species reported from Galápagos, will probably prove distinct when more material becomes available. All are species that have not diverged sufficiently since the closure of the Isthmus of Panama to be recognized by taxonomists as different species, although the populations are completely separated, and it is presumed that no gene flow occurs between them.

2.4.3a. Atlantic Analogues. If it were only for the species common to the two oceans, Atlantic and Pacific, the relationship between the Galápagos fauna and that of the West Indies would be a relatively weak one. Strengthening it immeasurably are the "twin" or geminate species, occurring on each side of the Isthmus of Panama. These are species that are more closely related to each other than are other species, such as replace each other from one faunal region to another throughout the world. They are recognized, not only among crabs, but among echinoderms, fishes, and other groups, and are considered prima facie evidence that the two oceans were confluent across the Isthmus of Panama in comparatively recent geological times, probably late Miocene (Durham and Allison, 1960).

Some 38 species of Galápagos brachyurans were recognized as having such analogues in 1946. This number has been increased by the discovery in the Galápagos of new species like Pinnixa darwini Garth 1960, whose closest relative and undoubted Atlantic analogue is P. faxoni Rathbun 1918 from Trinidad. The number has been decreased by finding that the Galápagos species of Tyche is not $T$. lamellifrons Bell 1835, the Panamic species and analog of the Atlantic T. emarginata White 1847 , but an endemic species, T. galapagensis Garth 1958 . These 
changes tend to cancel each other out, leaving the present list with 38 Galápagos species with analogues.

\subsubsection{Indo-Pacific Species}

As developed in a series of papers (the latest of which was Garth, 1974), the brachyuran crabs that are common to both western and eastern Pacific waters are mostly those that inhabit reef-building corals. These are Trapezia ferruginea and T. digitalis, Domecia hispida, and Hapalocarcinus marsupialis in the coral Pocillopora and Jonesius triunguiculatus in the coral Pavona, to which may now be added the coral-burrowing species Pseudocryptochirus crescentus (Edmondson). The other group that transgresses the Pacific Oceanic Barrier (Hawaii to California, or Tuamotu to Chile) are the pelagic grapsoids Plagusia immaculata, the Pacific log rider, and Planes cyaneus, the turtle crab. Gone are the circum-tropical grapsoids of 1946, Grapsus grapsus becoming amphi-American and west African, replaced in the Indo-west Pacific by G. tenuicrustatus (Herbst, 1783).

To my knowledge, no comprehensive resurvey of the Brachyura has been attempted since the severe incursion of El Niño in the early 1980's. It would not be unexpected to find that there has been an invasion of western Pacific species, some of which may become permanently established in the Galápagos Islands.

\subsubsection{Temperate South American Species}

These are poorly represented in the Galápagos Islands, despite the proximity of Cape Blanco, the Peruvian promontory that deflects the Peru Current northwestward toward the archipelago. Some, like Mursia gaudichaudii and Stenorhynchus debilis, are Panamic species whose ranges extend south, as well as north, of the tropics, well into temperate waters. Others, like Geograpsus lividus and Pachygrapsus transversus, while limited to tropical waters in the north, apparently stray into southern temperate waters. True temperate south Pacific species are Microphrys aculeatus and Pinnaxodes chilensis, the former free-living, the latter commensal with the sea urchin, Strongylocentrotus gibbosus. Clearly, the Galápagos brachyuran fauna shows little effect of south-temperate invasions.

\subsubsection{Species Absent from the Galápagos}

Of equal importance in assessing the brachyuran fauna of the Galápagos, or of any other island group, are the species that should be there, but are not. For example, the mangrove crab, Aratus pisonii, found in mangrove swamps along both the Atlantic and Pacific coasts of tropical America, does not occur in the Galápagos Islands, although mangrove trees are found on many of the islands. Similarly, land crabs of the genus Gecarcinus do not occur in the Galápagos, although G. planatus occurs on Clipperton Island and G. malpilensis on Malpelo Island, where each is a dominant land form. Nor do land crabs of the genus Cardisoma occur in the Galápagos, although $C$. crassum is found at Cocos Island, where it burrows at the base of coconut palms, which are also absent from the Galápagos. One may conclude either that their larval stages never reached the archipelago, or that, having reached it, they found conditions unsuited to their survival. Thus chance 
has played a role in the "sweepstakes" route that leads to successful colonization of the Galápagos marine environment.

The absence of the entire family Goneplacidae, and of most of the family Xanthidae, subfamily Panopeinae, the exceptions being Eurytium affine and Hexapanopeus cartagoensis, is more readily explainable. These are the mud crabs, and, with the exception of the mangrove lagoon, mud habitats are lacking in the Galápagos. In particular, the detritus-rich mud that is carried down from the Andes by such rivers as the Guayas in Ecuador, or the Atrato in Colombia, is absent from these islands, which have no such runoff. Their oceanic waters are shared by other islands and island groups, such as the Revillagigedos (Socorro, Clarion, San Benedicto), Clipperton, Cocos, and Malpelo. In various combinations, these islands (and the tip of Baja California) share with the Galápagos a number of brachyuran species not found on the adjacent mainland, for which the term "insular endemic" has been coined.

\section{Ecology of Galápagos Brachyura}

\subsection{Introduction}

Located on the Equator, the Galápagos Islands are warm, though tempered by the cold Peru Current. Their shores, of volcanic rock and sand, break the long Pacific swells into a surf that oxygenates their coastal waters, provides a variety of habitats, and brings an abundance of food. Absent are the great rivers of the continent that dilute the salt water, muddy it for hundreds of miles, and cover the ocean bottom with gas- and bacteria-producing detritus. Near enough to the mainland to participate in the wealth of forms characteristic of continental waters, yet sufficiently remote to have evolved forms of their own, the Galápagos Islands offer the ecologist a promising field for the pursuit of his studies.

In any classification of animals according to their habitat, the Brachyura are but a small segment of the whole. Necessary to the interpretation of the complex picture are the results of studies on the coelenterates, echinoderms, mollusks, annelids, fishes, reptiles, and birds. Specialists in all these groups participated in early voyages of the Velero III, under the command of Captain Allan Hancock, which visited the islands in 1932, 1933, 1934, 1935, and 1938. Their results, together with mine, appear in many volumes of the Hancock Pacific Expeditions and its sequels, the Monographs, Occasional Papers, and Technical Reports of the Allan Hancock Foundation. As my contribution to these others, and to an allembracing ecology yet to be written, I present this brief consideration of brachyuran habitats and associations within the waters of the Galápagos Islands.

\subsection{Types of Brachyuran Habitats}

\subsubsection{Above High Tide Line (Supra Tidal)}

3.2.1a. Spray Zone. Along the rocky shore, perpetually moistened by the spray that rises from the breaking waves, is the spray zone. It is the home of those 
Brachyura that are in the process of becoming terrestrial, but have not yet become emancipated from the sea. The most evident member of the spray zone fauna is the ubiquitous "Sally Lightfoot" crab (Grapsus grapsus). Wherever one lands on rocky shore, one is met by a small regiment of these bright red and yellow grapsids, contesting every foot of one's advance. More secretive, Geograpsus lividus hides in moist crevices, from which it rarely ventures forth in daytime. These crabs have long, slender legs for rapid transit, powerful muscles for jumping from rock to rock, and nail-like dactyls for holding themselves to porous lava. Their bodies are compressed, enabling them to force their way into narrow crevices. 'They follow the receding tide, keeping always out of water but in the spray, which constantly moistens their gill chambers. G. grapsus has been observed feeding, on sea lettuce, or Ulva, but is also known to be a scavenger. Spray zone species belong to the family Grapsidae, placed next to the family Gecarcinidae, containing the true land crabs, in systematic treatises. They are almost, but not quite, terrestrial.

\subsubsection{Between Tide Levels (Tidal)}

3.2.2a. Depositing Shore. The fine coral sand that alternates with rocky promontories along the Galápagos coastline supports an entirely different fauna. There is no spray zone on the sandy beach because the waves roll in smoothly, spreading a thin sheet of solid water to their uppermost reaches. In a situation roughly analogous to that occupied by the grapsids on rocky shore, namely, the highest level attained by moisture, lives the ocypodid crab, Ocypode gaudichaudii. He is the color of sand, and he runs over it so rapidly as to deserve the name "El Carretero," the cart driver, given him by the natives of Peru. At first sign of danger he withdraws into the mouth of his burrow, from which he surveys the world through periscopic eyes. His cylindrical body closes the aperture, and a heavy claw with truncate pincers bars access to the tunnel, which extends an arm's length or more to water level.

The pebble beach is less susceptible to wave action than the coral sand because of the larger size of the particles. It is not as stable as solid rock, however, and, because of the constant friction of pebble on pebble, no plant, sponge, coelenterate, or other sessile form can establish itself. These loose stones are inhabited by a different set of crab species from what one finds on solid rock. Known collectively as "pebble crabs," they belong to the family Xanthidae. Their most noticeable characteristic is the thickening of their carapace and chelipeds until they come to resemble the pebbles among which they hide, and they are capable of withstanding the same sort of abrasive treatment. Nor do they scuttle away if disturbed, but "freeze" in place, hoping thereby to escape detection. Lophoxanthus lamellipes, Xanthodius cooksoni, and the species of the genus Ozius, O. perlatus, $O$. verreauxii, and the former $O$. (now Epixanthus) tenuidactylus, are typical species of this habitat. The first two favor situations high upon the beach, where the only moisture is that left by the receding tide beneath the pebbles, the upper surfaces of which are dry and hot under the equatorial sun. The Ozius species, particularly $O$. perlatus and the former $O$. tenuidactylus, may be found by the hundreds in pockets of solid rock in which pebbles have accumulated, as at James Bay, Isla Santiago.

3.2.2b. Eroding Shore. The solid rock that is being slowly worn away by wave action is predominantly of volcanic origin. It is either basaltic, hence smooth, as at 
Darwin Bay, Isla Genovesa, or scoriaceous, hence rough, as in the majority of situations. Sedimentary rock was observed at beach level in but two Galápagos localities: at Baltra Island and at Floreana Island, near Cormorant Point. Here the purple bristle crab, Eriphides hispida, has riddled the crumbling cliffs with its shallow burrows.

Because of its great stability, solid rock provides the required foundation for the complex communities of algae, sponges, coelenterates, tunicates, ascidians, barnacles, and other sessile forms that provide footholds, concealment, food, and adornment for crabs and other free-living creatures. Because of the great variety of habitats and associations thus provided, the crab life of the rocky shore is rich in number of species in contrast to the meager representation is shifting sand and swirling pebbles.

Some of the richest stations established by early Hancock expeditions, including station 69-33, were along the east shore of Isla Isabela, from Albemarle Point to Cartago Bay, where a series of rocky promontories alternates with sandy beaches. Here Platypodiella gemmata, previously known only from the type specimen and a few specimens obtained by the Crossland Expedition (Finnegan, 1931), was found abundantly when it was learned that it excavates a hollow for itself in sponges. Likewise, the grapsid crab, Percnon gibbesi, not previously encountered in the Galápagos Islands, was obtained through the accidental discovery of its particular habitat, the under sides of turnable boulders in knee- to hip-depth water, thoroughly aerated by the surf.

As so large a number of Galápagos Brachyura occur on rocky shore, it is not possible to discuss them individually. A typical list from the rocky shore at Sulivan Bay, Isla Santiago, station 343-35, together with the numbers of individuals observed on a single low tide, follows:

Dromidia larraburei

Dynomene ursula

Herbstia pyriformis

Herbstia edwardsii

Mithrax nodosus

Teleophrys cristulipes

Tyche galapagensis

Daldorfia garthi

Liomera cinctimana

Daira americana
1 Platyactaea dovii

9 Cycloxanthops vittatus

3 Xanthodius cooksoni

4 Lophoxanthus lamellipes

22 Paraxanthias insculptus

26 Microcassiope xantusii

1 Epixanthus tenuidactylus

1 Eriphia granulosa

1 Eriphides hispida

3 Pachygrapsus transversus
12

2

3

6

7

21

5

40

1

1

From the list just given it may be seen that the dominant species were Mithrax nodosus, Eriphia granulosa, Teleophrys cristulipes, and Microcassiope xantusii. Of lesser abundance, but common, were Platyactaea dovii, Dynomene ursula, Paraxanthias insculptus, Lophoxanthus lamellipes, and Epixanthus tenuidactylus. The balance, represented by three specimens or less, might be considered rare.

3.2.2c. Mangrove Association. The brackish lagoon is the habitat of the species of Uca, or fiddler crabs $U$. galapagensis and $U$. helleri, both Galápagos endemic species. They are confined to colonies in a few sheltered areas, as at Cormorant Point, Isla Floreana, at Academy Bay, Isla Santa Cruz, at James Bay, Isla Santiago, and at Darwin Bay, Isla Genovesa. The lagoons are fringed with mangrove 
trees, the roots of which form an impenetrable thicket and provide shelter for the burrows. The two species of Uca occupy different localities, or, if the same locality, as at Academy Bay, separate coves. The colonies remain distinct; the species do not mingle. It would seem that some slightly different requirement must be met for each in the way of habitat. At Darwin Bay, Isla Genovesa, and at Mangrove Point, Isla Fernandina, where only $U$. helleri occurs, the inlets are drained by estuarine outfall, whereas at Isla Floreana and Isla Santiago, where U. galapagensis is found, only seepage drainage occurs. At Academy Bay, where both species are found, $U$. galapagensis occurs at greater distance from the sea. Apparently it is more tolerant of the salinity that develops as the shallow sheet of water evaporates.

\subsubsection{Just Below Low Tide (Adtidal)}

3.2.3a. Corals. Exposed at extreme low tide, and seldom covered by more than $4 \mathbf{m}$ of water, are the reef-building corals of the genera Pocillopora and Pavona. The former is in the shape of a head of cauliflower, with many branches. The latter is the massive "brain" coral, with convoluted ridges. In the protective labyrinth of passageways provided by the corals, and particularly by the Pocillopora coral, are to be found species of Brachyura that do not occur in any other habitat, as well as species that find in the coral the same type of physical shelter they would seek from any other solid object of irregular shape.

Species that inhabit Pocillopora coral exclusively are, in the eastern Pacific, members of the family Xanthidae. They include the species of Trapezia, T. ferruginea and T. digitalis, Domecia hispida, and Liomera cinctimara. Of these, the Trapezia species dominate, T. ferruginea outnumbering $T$. digitalis by about four to one. A number of other species are found commonly in Pocillopora coral, as well as in other sheltered crevices at low tide:

Platyactaea dovii

Paractaea sulcata

Globopilumnus xantusii

Pilumnus pygmaeus
Microcassiope xantusii

Daira americana

Paraxanthias insculptus

"Micropanope" fraseri

A few other species, such as Cycloxanthops vittatus and Acidops fimbriatus, are less often encountered in Pocillopora than free living. Of the exclusively coralinhabiting species, only Trapezia ferruginea had been recorded from the Galápagos Islands previous to the Hancock expeditions, and that by but a single specimen (Boone, 1927).

Several heads of massive brain coral, genus Pavona, weighing several hundred pounds each, were grappled from a depth of $4 \mathrm{~m}$ off Onslow Island, and examined for commensals. In each was found a small crab with affinities to the western Pacific and Indian oceans! Believed to be an endemic species, it was first named Maldivia galapagensis Garth 1939, but is now known as Jonesius triunguiculatus (Borradaile 1903) (See Galil and Takeda, 1986). None of the brachyuran species common to Pocillopora was found in Pavona, nor was any other brachyuran species encountered. With the Jonesius, however, was the peculiar shrimp, Discias serrifer Rathbun, for which the habitat was previously unknown.

The gorgonian coral or sea fan, Muricea miser (Verrill), is the habitat of the xanthid crab, Quadrella nitida, of which a single specimen was found by the Velero 
III in Galápagos waters. For a classic description of the remarkable association of this crab and gorgonian, see Crane (1937).

3.2.3b. Worm Tubes. From the tubes of the annelid worm, Chaetopterus variopedatus (Renier) were taken a male and female specimen of the pinnotherid crab, Pinnixa transversalis, a species common along the mainland coast of South America from Panama to Patagonia, but not previously recorded from the Galápagos Islands (Garth, 1946a). At Tagus Cove, Isla Isabela, two females of a new species of Parapinnixa, P. glasselli, were taken from a "roach" trap attached to a lobster pot suspended in $4 \mathrm{~m}$ of water (Garth, 1946a). No record of the host was obtained, but it was presumed to be a worm also, the carapace and first ambulatory legs of the crab being transversely cylindrical in adaptation to the tubiculous habitat.

3.2.3c. Echinoderms. The sea urchin Caenocentrotus gibbosus (L. Agassiz and Desor.) is the host of the pinnotherid crab Pinnaxodes chilensis, commensal in its periproct. This crab is commonly found in the urchin in Peruvian waters and was first noted from the Galápagos Islands by H. L. Clark (1902), in reporting the echinoderms of the Hopkins-Stanford Expedition. He did not refer to it by name, and it remained for Schmitt (1939) to record P. chilensis from the Galápagos Islands. The presence of the crab in the urchin can be told by external examination because of the swollen test. More recently, the sea urchin Lytechinus semituberculatus, was found by G. M. Wellington to host the pinnotherid crab Pinnotheres pubescens Holmes, or a closely related species. The crab occurs on the oral area of the urchin.

\subsubsection{Deeper Water}

The waters of the Galápagos Islands are crystal clear, owing to the clean nature of the bottom, which is uniformly composed of white coral sand with patches of lava rock protruding. The sand is frequently accompanied by rounded particles of stony corals in process of disintegration, and by nullipore corals, living or dead. Broken shells sometimes occur in sufficient numbers to have been noted in dredge hauls, as at Isla Wolf. Rock beneath the surface supports algal life to the limit of penetration of sunlight, and animal life to deepest levels. Algae are mainly of two kinds: red algae and pink or purplish coralline. Heavy encrustations of sponges, hydroids, and bryozoans are commonly torn loose from solid rock or brought up in the dredge on loose boulders.

Because sand and rock occur in close proximity in bays and along coastlines of the Galápagos Islands, it was difficult to make dredge hauls exclusively of one or other type of bottom. The dredge frequently surfaced with the sand completely washed out and the sand-inhabiting animals macerated by the few pieces of rock that were not their true habitat. The accompanying characterization of brachyurans according to bottom type inhabited is therefore only an approximation, as it is based upon the various types of bottom material recovered with each species.

3.2.4a. Rock Bottom. The following are predominantly rock-dwelling species, often associated with red or coralline algae. The alga is used by spider crabs as decoration; the coralline is matched by xanthid crabs for concealment: 
Lissa aurivilliusi

Lipaesthesius leeanus

Microphrys triangulatus

3.2.4b. Sand Bottom. The following are predominantly sand-dwelling species, often with dead coral, broken shell, and nullipore:

Notosceles ecuadorensis

Ranila fornicata

Hypoconcha panamensis

Ethusa lata

Clythrocerus laminatus

Ebalia hancocki

Calappa convexa

Randallia agaricias

Mursia gaudichaudii

Cycloës bairdii

Osachila galapagensis

Osachila levis

Stenorhynchus debilis

Anomalothir hoodensis

Podochela schmitti

Euprognatha granulata

Sphenocarcinus agassizi

Mithrax mexicanus
Stenocionops ovata

Parthenope triangula

Parthenope depressiuscula

Solenolambrus arcuatus

Mesorhoea bellii

Portunus stanfordi

Portunus angustus

Portunus tuberculatus

"Lophopanopeus" maculatus

Hexapanopeus cartagoensis

Ectaesthesius bifrons

Acidops fimbriatus

Kraussia americana

Palicus cortezi

Palicus fragilis

Palicus velerae

Palicus lucasii

Euchirograpsus pacificus

3.2.4c. Sand and rock Bottom. The following may be either sand- or rockdwelling:

Dromidia larraburei

Edwardsium lobipes
Edwardsium crosslandi

Nanocassiope polita

3.2.4d. Bottom insufficiently known. The following do not appear in one of the above lists because of inadequate sampling:

\section{Lithadia cumingii \\ "Actaea" angusta}

Tetraxanthus rathbunae

Microphyrys platysoma

\subsubsection{Pelagic}

While many, if not most species of Brachyura are pelagic in the early life stages of zoeae and megalopa, very few are pelagic as adults. In the Galápagos Islands the only species found by Velero III scientists at the surface as adults were members of the family Portunidae, the swimming crabs. On one occasion a dozen of the stalkeyed Euphylax dovii came to the gangway light at Tagus Cove, Isla Isabela, and were dipped with a long-handled net. On another occasion, at Conway Bay, Isla Santa Cruz, four specimens of Portunus stanfordi were captured similarly, and at Aeolean Bay, Isla Baltra, Portunus angustus came to light. The latter two species were dredged abundantly, but Euphylax was found by Velero III parties only at the surface.

The Pacific log rider, Plagusia immaculata, was not encountered by the Velero III in Galápagos waters, although it has been recorded (Boone, 1927), but was taken 
by Gerard Wellington from the hull of a tourist vessel that operates in the Galápagos full time. Nor was the ubiquitous Planes cyaneus discovered in Galápagos waters by Velero III parties, although several green sea turtles were overturned and examined. Rathbun (1918, p. 257) records "Off Galápagos Islands, from a green turtle." Wellington discovered it in 1974 at Punta Suarez, Isla Española, but the host, if any, was not mentioned.

It is noteworthy that there are no kelps in the Galápagos Islands. Algal communities are dominated either by red or green, seldom brown algae. An exception was the Sargassum, from which were obtained specimens of Acanthonyx petiverii, a member of the family Majidae, subfamily Acanthonychinae, to which the well known Epialtus of temperate shores belongs.

\subsubsection{Unexplored}

Two habitats that were not explored by Hancock or earlier expeditions became accessible only with the advent of self-contained underwater breathing apparatus (SCUBA). These were the vertical walls of steep-sided cliffs, as at Malpelo Island, Colombia, and the newly discovered anchialine caves, described by Iliffe in Chapter 10 of this volume. The former can be treated as subtidal rocky shore, having, like the intertidal rocky shore, a solid substrate, to which corals and coralline algae attach, as do sponges, hydroids, and algae. Specimens obtained by SCUBA divers from such vertical surfaces are the same as those encountered at extreme low tide on rocky shore. The few crabs recovered to date from anchialine caves in the Galápagos are still under study, but preliminary examination suggests that this unique environment has produced modifications on its brachyuran inhabitants that should be explored further.

\section{Note Added in Proof}

Since this chapter has gone to press, the former Micropanope fraseri Garth, 1946, has been placed in the new genus Garthiope Guinot (1990), and the first of the two crabs recovered from Galápagos anchialine caves, Garthiope anchialina Guinot and Iliffe (1991), has been described and illustrated. The second crab is being studied.

\section{References}

Bell, T., 1835, Some accounts of the Crustacea of the coasts of South America, with descriptions of new genera and species, founded principally on collections obtained by Mr. Cuming and Mr. Miller, Proc. Zool. Soc. London 3:169-173.

Bell, T., 1836, [Same Title], Trans. Zool. Soc. London 2:39-66.

Bell, T., 1855, A monograph of the Leucosiadae, with observations on the relations, structure, habits, and distribution of the family; a review of the generic characters; and descriptions of new genera and species, Trans. Linn. Soc. London 21:277-314.

Boone, L., 1927, The littoral crustacean fauna of the Galápagos Islands, Part I: Brachyura, Zoologica 8:127-288.

Borradaile, L. A., 1903, Marine Crustaceans, III, The Xanthidae and some other crabs, in: Fauna and Geography of the Maldive and Laccadive Archipelagoes, Volume 1 (J. S. Gardner, ed.), University Press, Cambridge, pp. 237-271. 
Castro, P., 1982, Notes on symbiotic decapod crustaceans from Gorgona Island, Colombia, with a revision of the eastern Pacific species of Trapezia (Brachyura, Xanthidae), symbionts of scleractinian corals, An. Inst. Inv. Mar. 12:9-17.

Clark, H. L., 1902, Papers from the Hopkins-Stanford Galápagos Expedition, 1898-1899, XII, Echinodermata, Proc. Washington Acad. Sci. 4:521-531.

Crane, J., 1937, The Templeton Crocker Expedition, III, Brachygnathous crabs from the Gulf of California and the west coast of Lower California, Zoologica 22:47-78.

Desbonne, I., 1867, Desbonne comparé avec les Echantillons de Crustacés de sa collection et les dernières publications de MM. H. de Saussure et W. Stimpson, I. Partie, Brachyures, in: (I. Desbonne and A. Schramm) Crustacés de la Guadeloupe, (publisher and city unknown), Bas-Terre (The Netherlands], pp. 1-160.

DiMauro, A., 1982, Rediscovery of Professor Thomas Bell's type Crustacea (Brachyura) in the dry crustacean collection of the Zoological Collections, University Museum, Oxford, Zool. J. Linn. Soc. London 76:155-182.

Durham, J. W., and Allison, E. C., 1960, The geologic history of Baja California and iss marine faunas, in: The geologic history of Baja California and Adjacent Seas (Symposium), Part 1, Geologic History, Syst. Zool. 9:47-91.

Finnegan, S., 1931, Report on the Brachyura collected in Central America, the Gorgona and Galápagos Islands, by Dr. Crossland on the "St. George" Expedition to the Pacific, 1924-25, J. Linn. Soc. London, Zool. 37:607-693.

Forest, J., and Guinot, D., 1961, Crustacés Décapodes Brachyoures de Tahiti et des Tuamotu, in: Expédition française sur les récifs coralliens de la Nouvelle-Calédonie, Volurne préliminaire, pp. 1-195, Editions de la Fondation Singer-Polignac, Paris.

Galil, B., and Takeda, M., 1986, Resurrection of the genus Jonesius and establishment of a new genus: Commensal crabs associated with corals from the Indo-Pacific Ocean, Bull. Natl. Sci. Mus. (Tokyo) A, 12:163-171.

Garth, J. S., 1939, New brachyuran crabs from the Galápagos Islands, Allan Hancock Pacif. Exped. 5: 9-29.

Garth, J. S., 1946a, Littoral brachyuran fauna of the Galápagos Archipelago, Allan Honcock Pacif. Exped. 5:341-601.

Garth, J. S., 1946b, Distribution studies of Galápagos Brachyura, Allan Hancock Pacif. Exped. 5: $603-638$.

Garth, J. S., 1955, The case for a warm-temperate fauna on the west coast of North America, in: Essays in the Natural Sciences in Honor of Captain Allan Hancock, pp. 19-27, University of Southern California Press, Los Angeles.

Garth, J. S., 1958, Brachyura of the Pacific Coast of America, Oxyrhyncha, Allan Honcock Pacif. Exped. 21:1-854.

Garth, J. S., 1960, Pinnixa darwini, a new species of pinnotherid crustacean from the Galápagos Islands, Pacif. Sci. 14:39-42.

Garth, J, S., 1965, The brachyuran decapod crustaceans of Clipperton Island, Prcc. Calif. Acad. Sci. (series 4)33:1-46.

Garth, J. S., 1968, Globopilumnus xantusii (Stimpson), n. comb., a stridulating crab from the west coast of tropical America, with remarks on discontinuous distribution of some West American and West African genera of brachyrhynchous crabs, Crustaceana 15:312-318.

Garth, J. S., 1974, On the occurrence in the eastern tropical Pacific of decapod crustaceans commensal with reef-building corals, Proc. 2nd Intl. Coral Reef Symp. (Brisbane) 1:397-404.

Garth, J. S., and Hopkins, T. S., 1968, Pseudocryptochirus crescentus (Edmondson), a second crab of the corallicolous family Hapalocarcinidae (Crustacea Decapoda) from the eastern Pacific, with remarks on phragmosis, host specificity, and distribution, Bull. South. Calif. Acad. Sci. 67:40-48.

Garth, J. S., and Stephenson, W., 1966, Brachyura of the Pacific Coast of America, Brachyrhyncha: Portunidae, Allan Hancock Monogr. Mar. Biol, 1:1-154.

Gerstaecker, K. E. A., 1857, Carcinologische Beiträge, Arch. f. Naturg. 22:101-162.

Glassell, S. A., 1936, The Templeton Crocker Expeditions, 1, Six new brachyuran crabs from the Gulf of California, Zoologica 31:213-218.

Goeke, G. D., 1981, Symethinae, new subfamily, and Symethis garthi, new species, and the transfer of Raninoides ecuadorensis to Notosceles (Raninidae; Brachyura; Gymnopleura), Proc. Biol. Soc. Washington 93:971-981. 
Guinot, D., 1964, Les trois espèces du genre Domecia (Decapoda, Brachyura): D. hispida Eydoux \& Souleyet, D. glabra Alcock, et D. acanthophora (Desbonne and Schramm), Crustaceana 7:267-283.

Guinot, D., 1966, Recherches préliminaires sur les groupements naturels chez les Crustacés, I. Les affinités des genres Aethra, Osachila, Hepatus, Hepatella, et Actaeomorpha (suite et fin), Bull. Mus. Natl. Hist. Nat. (Paris), sér. 2 38:828-845.

Guinot, D., 1967a, [Same title], II, Les anciens genres Micropanope Stimpson et Medaeus Dana, Bull. Mus. Natl. Hist. Nat. (Paris), sér. 2 39:345-374.

Guinot, D., 1967b, [Same title], III, A propos des affinités des genres Dairoides Stebbing et Daira de Haan, Bull. Mus. Natl. Hist. Nat. (Paris), sér. 2 39:540-563.

Guinot, D., 1968, [Same title], IV, Observations sur quelques genres de Xanthidae, Bull. Mus. Natl. Hist. Nat. (Paris), sér. 2 39:695-727.

Guinot, D., 1969, Sur divers Xanthidae, notamment sur Actaea de Haan et Paractaea gen. nov. (Crustacea Decapoda Brachyura), Cah. Pacif. 13:222-267.

Guinot, D., 1971, Recherches préliminaires sur les groupements naturels chez les Crustacés Décapodes brachyoures, VIII, Synthèse et bibliographie, Bull. Mus. Natl. Hist. Nat. (Paris), sér. 2 42:1063-1090.

Guinot, D., 1976, Constitution de quelques groupes naturels chez les Crustacés Décapodes Brachyoures, I, La superfamille des Bellioidea et trois soufamilles des Xanthidae (Polydectinae Dana, Trichiinae de Haan, Actaeinae Alcock), Mém. Mus. Natl. Hist. Nat. (Paris), sér. A Zool. 97:1-308.

Guinot, D., 1990, Établissement du genre Garthiope gen. nov., ses relations avec le genre Coralliope Guinot, 1967, et leurs affinités avec les Trapeziidae sensu lato (Crustacea Decapoda Brachyura), Bull. Mus. Natl. Hist. Nat. (Paris), sér. 4, 12, sec. A, 2:469-487.

Guinot, D., and Iliffe, T. M., 1991, Garthiope anchialina sp. nov., espèce anchialine des Galápagos, île Isabela, Cueva de la Cadena, avec remarques sur la faune carcinologique anchialine (Crustacea Decapoda Brachyura), Bull. Mus. Natl. Hist. Nat. (Paris), sér. 4, 12 (1990), sec. A, 3-4:607-621.

Holmes, S. J., 1900, Synopsis of the California stalk-eyed Crustacea, Occas. Pap. Calif. Acad. Sci. 7: $1-262$.

Holthuis, L. B., 1979, A small collection of decapod crustacea from Galápagos Islands, Spedizione $L$. Mares-G.R.S.T.S., pp. 1-11, Firenze, Italy.

Holthuis, L. B., and Gottlieb, E., 1958, An annotated list of the Decapoda Crustacea of the Mediterranean coast of Israel, with an appendix listing the Decapoda of the Eastern Mediterranean, Bull. Res. Council Israel 78:1-126.

Menzies, R. J., 1948, A revision of the brachyuran genus Lophopanopeus, Occas. Pap. Allan Hancock Found. 4:1-45.

Milne Edwards, A., 1880, Reports on the results of dredging under the supervision of Alexander Agassiz in the Gulf of Mexico, 8, Etudes préliminaires sur les Crustacés, pt. 1, Bull. Mus. Comp. Zool., Harvard 8:1-68.

Monod, T., 1956, Hippidea et Brachyura ouest-africains, Mém. IFAN, 45:1-674.

Rathbun, M. J., 1910, The stalk-eyed Crustacea of Peru and the adjacent coast, Proc. U.S. Nat. Mus. 38:531-620.

Rathbun, M. J., 1911, The Percy Sladen Trust Expedition in the Indian Ocean in 1905 under the leadership of Mr. J. Stanley Gardiner, Volume III, No. XI, Marine Brachyura, Trans. Linn. Soc. London ser. 2, Zool. 14:191-261.

Rathbun, M. J., 1981, The Grapsoid Crabs of America, Bull. U.S. Nat. Mus. 97:1-461.

Sakai, T., 1976, Crabs of Japan and Adjacent Seas, Kodansha, Ltd., Tokyo.

Sankarankutty, C., 1962, On Decapoda Brachyura from the Andaman and Nicobar Islands: 2, Family Xanthidae, J. Mar. Biol. Assoc. India 4:121-150.

Schmitt, W. L., 1936, Hancock Pacific Expedition, 1935, Explorations and Fieldwork of the Smithsonian Institution in 1935, pp. 29-36.

Schmitt, W. L., 1939, Decapod and other Crustacea collected on the Presidential Cruise of 1938 (with introduction and station data), Smithson. Misc. Coll. 98:1-29.

Smith, S. I., 1869, in A. E. Verrill, On the parasitic habits of some Crustacea. Amer. Nat. 3:239-250.

Stimpson, W., 1871, Notes on North American Crustacea in the Museum of the Smithsonian Institution, No. 3, Ann. Lyc. Nat. Hist. New York 10:92-136.

Türkay, M., 1975, Zur Kenntnis der Gattung Euchirograpsus mit Bemerkungen zu Brachygrapsus und Litocheira (Crustacea: Decapoda], Senckenbergiana Biol. 56:103-132.

Wellington, G. M., 1976, A prospectus: Proposal for a Galápagos Marine Park, Noticias de Galapagos 24:9-13. 